\title{
J
}

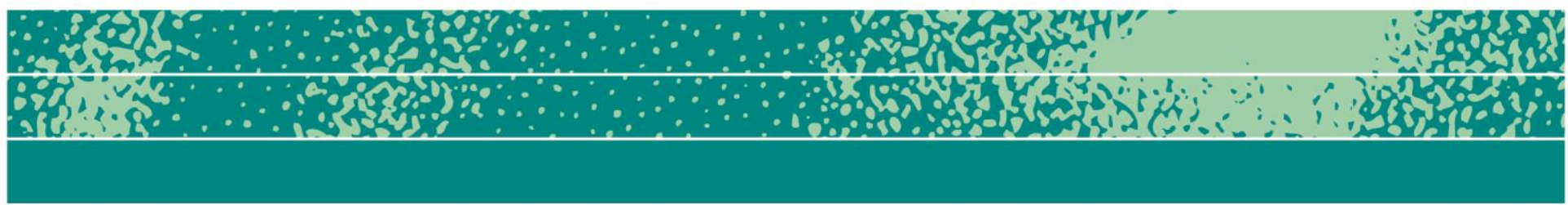

\section{Producing "global" corporate subjects in post-Mao China: Management consultancy, culture and corporate social responsibility}

\author{
Kimberly Chong
}

\begin{abstract}
China's rampant economic modernization-much discussed, vaunted, and criticised-has led to an influx of foreign corporations. Along with substantial investment they usher in new problems of modernity. Most pressing, at least from the perspective of Western managers, is how to "reengineer" the Chinese knowledge worker to think and behave in accordance with global business norms. Drawing on 16 months fieldwork inside the China arm of global management consultancy, this article examines the ways in which the internal practice of corporate social responsibility (CSR) is used to "civilize" Chinese employees in a global ethics. Through ethnographic analysis of various "corporate citizenship" initiatives, I track the ways in which these performances of morality feed into an "imaginary of a moral self." I also point out the discursive limits to these processes and argue that CSR, which has been criticized as a modern re-incarnation of Western paternalism and corporate imperialism, is a discursive formation which is incompatible with the post-Mao context where economic development and morality is mainly controlled by the state. Furthermore, I show that corporate ethicizing, although often characterised as an extra-financial disposition, is
\end{abstract} Page 1 of 22

JBA 4(2): 320-341 Fall 2015

(C) The Author(s) 2015 ISSN 2245-4217

www.cbs.dk/jba 
subsumed into the work of making "engaged employees"-defined as those who are productive of shareholder return.

\section{Keywords}

Corporate social responsibility, morality and ethics, culture, China, shareholder return.

In the mid-eighteenth century, several thousand Chinese laborers travelled to California with the hope of finding gold. In recent years we have seen another "gold rush." This time it is the Western business elite who have travelled across the world to make their fortune. Encouraged by a host of government incentives, they have flocked to the metropolises of Shanghai, Beijing and Guangzhou to mine the lucrative "China market." Spearheading the nascent operations of large multinationals, Western executives often struggle to cope with the pace of expansion. In particular, they complain that they cannot find the right kind of employees. As Aihwa Ong has pointed out, this is not conceived as a problem of technical expertise. Rather there exists a widespread perception amongst Western managers that Chinese workers, whilst well educated for their jobs, do not display the requisite social knowledge and dispositions befitting employees of global entities (Ong 2006). ${ }^{1}$

Under Mao Zedong China ran an autarkic regime in which workers enjoyed lifelong employment in state run "work units" (danwei), shielded from the pressures of market competition in a socialist command economy. During this time, almost all aspects of public and private life were subject to state control. The Chinese Communist Party even sought to influence people's thoughts (Lynch 1999). ${ }^{2}$ In the four decades since Mao's death, China has embraced market capitalism and become firmly integrated into the global economy. It has captured the lion's share of manufacturing work, to become the second largest economy in the world. This dramatic contrast between China's present and recent past is often invoked in narratives which problematize the Chinese corporate subject. For example, Dimitri Kessler and Andrew Ross find that Western managers in China's software industry attribute the "deficiencies" of Chinese workers to their socialization in a context which

\footnotetext{
${ }^{1}$ According to Ong, Western managers in Shanghai consider "the reengineering of Chinese knowledge workers and the production of new business ethics the most challenging part of their work" (Ong 2006: 167).

${ }^{2}$ State intervention in private and public life endures in the post-Mao period of market socialism. In some senses, though, it has diminished. For example, people now have far greater choice and control in decisions regarding work and where they live. But in other ways intervention has become more invasive. One obvious example is the imposition of the draconian family planning rules, otherwise known as the "one-child policy."
} 
is portrayed as the antithesis of global capitalism. Ridding them of their "socialist" ways or "irrational" Chinese culture is posed as a managerial conundrum (Ross 2006, Kessler 2006), a hurdle to economic development which must be overcome if China is to move higher up "the value chain."

In this paper I follow Ong's injunction to pay attention to the managerial technologies which define corporate subjectivities, and I consider the new forms of sociality which are accompanying China's economic modernization. Whilst Ong's research focuses on how the conduct of Chinese employees is problematized by Western managers and discourses in mainstream business literature, I am interested in the actual practices which are deployed to transform the problematized Chinese worker into an idealized corporate subject "who will think and behave in accordance with global business norms" (Ong 2006: 171). I draw on sixteen months fieldwork inside the China arm of a Western global management consultancy which I will call Systeo. ${ }^{3}$ My analysis focuses on corporate social responsibility, or CSR, as a managerial tool of acculturation; specifically, I examine the ways in which the internal practice of CSR is used to "civilise" Chinese employees in the ways of global capitalism. Notions such as "the triple bottom line" (people, planet and profit) and "fair competitiveness" suggest that CSR operates by expanding economic value to subsume value social and ethical values (see Rajak 2011: 10; 2008). As Geert de Neve and his co-authors put it, CSR can be read "as an attempt by corporations to underscore [the claim] that a 'humane capitalism' is possible" (de Neve et al. 2008: 17). Elsewhere anthropologists, including Elana Shever, Marina Welker and Peter Benson, have focused on how CSR is deployed as a means of manipulating the external perceptions of corporate practice: that is, on how it feeds into corporate reputation, particularly in contexts like the extractive industries where the destructive aspects of capitalism are especially visible. By contrast, the argument I present here concerns how CSR is deployed internally to create social meaning for employees.

Although I am looking at the implementation of CSR in China, it is important to stress that the story I present here is not, however, one of overcoming "cultural difference." Rather, I suggest that the moulding of corporate subjectivity provides a useful forum to examine the connections between ostensibly de-politicized forms of morality and the economic interests of global business. I am interested in how morality is woven into the production of new forms of corporate personhood (Kirsch 2014), taking my lead from Dinah Rajak's insights about how corporations, through forms of story-telling, create an "imaginary of a moral self" which intensifies, rather than ameliorates, the most

\footnotetext{
${ }^{3}$ Systeo is a pseudonym. All informants' names have been anonymized, and potentially revealing details such as gender and ethnicity have been augmented where such details do not impair the argumentation.
} 
destructive elements of global capitalism. Writing about the mining company Anglo-American, Rajak argues that "narratives of philanthropy play a key role neither as the antithesis to the logic of capitalism, nor as the company's conscience, but as the warm-blooded twin to the violence of corporate imperialism" (2014: 266). However, I extend Rajak's argument by showing that embodied performances of morality also feed into an imaginary of a good corporate citizen.

For management consultants the making of moral legitimacy is particularly important; they rely on processes of conspicuous ethicizing to underwrite their otherwise hollow professional standing (Kipping 2011). Invested with extraordinary power to restructure organizations, management consultants are known for failing to deliver. Behind the headlines which highlight the millions (of public money) spent on failed IT management projects is a lingering doubt over consultants' expertise. ${ }^{4}$ What do consultants actually do and why do we entrust them to refashion our economy? The scope of their impact cannot be underestimated; almost all large public and private sector organizations will hire a management consultancy at some point. Changes to workplaces-such as the growth in outsourcing, the implementation of comprehensive IT systems, and the ubiquitous redefining of the organization as being primarily motivated by performance objectives-can all be traced to management consultants. They do more than advise: consultants produce forms of knowledge-business concepts, ideas and models. These are epistemological tools which create the legitimacy for them to carry out organizational interventions, and which may or may not have their intended effects. Indeed, it is in the event of failure that performing morality-being a good corporate citizen-becomes paramount.

In this article, I explore the projects of corporate citizenship through which employees are encouraged to embody a moral ethos: in particular, the annual charity bike ride-the most visible of Systeo China's corporate citizenship initiatives. Experiences of suffering, hardship and dislocation are part of an enactment of morality where employees are asked to relate to a "safe" Other to which they can direct their goodwill. In this way, the production of meaning and affect is carefully managed. However, as we will see, Chinese employees' interrogate the morality they are being invited to perform, suggesting that there are limits to which CSR can be depoliticized as a device of "shared global values" (Rajak 2011). I argue that CSR, which Rajak has criticized as a modern reincarnation of Western paternalism and corporate imperialism (ibid.), is a discursive formation which is incompatible with the post-Mao context where economic development and morality are mainly controlled by the state (Kipnis 2007). Second, I demonstrate that corporate ethicizing,

\footnotetext{
4 For example, "NHS has no idea what $£ 300$ m of management consultancy buys," The Guardian, 4 June 2009.
} 
although often characterized as an extra-financial disposition, ${ }^{5}$ is subsumed into the work of making "engaged employees"-defined as those who are productive of shareholder return. Hence, my analysis substantiates Rajak's observation that CSR is not conceived as a "moral bolt-on" to capitalism as usual, but rather the integration of ethical principles and praxis into corporations' core business (Rajak 2008).

\section{Fieldwork inside reflexive management production}

One of the first questions people ask when I tell them I carried out fieldwork inside a global management consultancy is: "how did you get access?" Many assume that consultants would be paranoid about having an anthropologist embedded amongst their ranks, not least because what I am interested in-the forms of knowledge and processes of valuation which underpin contemporary managerial techniques-is also what consultants sell. Management consultancies are the central institution in what Nigel Thrift terms the "cultural circuit of capital... [which is] responsible for the production and distribution of managerial knowledge" (Thrift 2005: 61). Consultants trade in reflexive business management: they sell knowledge of the "practicalities of business," which is, in turn, fed back into business practices. More than once I was accused, only halfjokingly, of being a corporate spy. But the fact that I was interested in the production of managerial knowledge could also be a selling point.

According to Greg Downey and Melissa Fischer, business anthropologists have become the exemplary reflexive managerial subject (Downey and Fischer 2006), a depiction which lends itself to corporate collaboration-especially in industries built on a foundation of reflexive knowledge such as advertising (Moeran 2006, Mazzarella 2003) and information technology (Cefkin 2010, Nafus and Anderson 2006). An anthropologist "for free" could be an attractive proposition if articulated in the right context.

My access was brokered with senior executives convinced of the efficacy of Systeo's corporate culture to produce exemplary corporate subjects. "Systeo culture" was frequently invoked as a social totality that would swallow anything in its path. Even the in situ anthropologist would not be able to escape its effects, a view espoused by one expatriate manager who told me: "by the time you leave here you will be Systeofied!" Perplexed by Chinese employees who did not display the desired subjectivity, expatriate management was open to the potential of anthropology to shed light on the situation. Many assumed that the problem lay with"Chinese culture:" the intractability of Chinese

\footnotetext{
${ }^{5}$ In simple terms CSR consists of practices and discourses in which business is portrayed as being concerned with more than just profit. They are good "corporate citizens" who stress the "triple bottom line" (accounting for "people" and "planet," as well as profit).
} 
employees, because of "their culture," to yield to Systeo acculturation. But others feared that the ineffective operation of corporate culture, a concept which was originally devised by management consultants, would threaten their status as knowledge experts and thus had potentially negative implications for the project of selling management knowledge externally.

After a stint as an English trainer to Systeo's back-office employees (who carry-out the routinized work of processing timesheets, expense claims, and arranging business travel of consultants), I was invited to participate in an internal management project concerning Systeo's corporate culture-the "human capital strategy programme." The ostensibly overlapping content of anthropological and consulting expertise-that of culture-surely facilitated, if not informed, the invitation. In any case, with this new position came a new means of producing anthropological knowledge-through collaboration with my research subjects (Holmes and Marcus 2006). Effectively, I was treated as an external consultant to Systeo's corporate culture-a position which conferred access to Systeo's HR department, internal corporate training, CSR initiatives, and entry to the various consulting offices in its China practice. However, after a year of access my motivations for carrying out work unpaid started to be questioned. Thus, for the last few months of fieldwork I took on a contractor role in the CSR division, helping to coordinate local CSR initiatives in the China practice.

By participating in initiatives of "corporate citizenship"-the vehicle through which CSR is implemented-it was hoped that employees would learn to perform the "core values" which formed the foundation of the firm's "corporate culture." Due to my commitment to anonymize Systeo to the best of my abilities, I am unable here to disclose the company's core values. However, it should be noted that companies in the professional services industry have strikingly similar core values, in spite of the explicit, or at least implicit, claims made on their websites that their core values form the basis of their distinct culture or "way of doing business." For example, Boston Consulting Group, Pricewaterhouse Coopers, and KKR-a consultancy, an accounting firm and consultancy, and private equity firm, respectively-all espouse core values of "integrity," "diversity/respect for the individual," and "innovation." Notably, however, Boston Consulting Group does not use the term innovation, preferring instead "Expanding the Art of the Possible." Historian Christopher McKenna observes that the two books which are widely cited as initiating the corporate culture movement in the 1980s, Corporate Culture: Rites and Rituals and In Search of Excellence, have strong links to McKinsey management consultancy's "brand" of professionalism (2006). The former was based on McKinsey's definition of corporate culture, whilst the latter was written by two McKinsey partners, Tom Peters and Robert Waterman, as part of a strategic decision 
to commodify the firm's professional practice (ibid.). ${ }^{6}$ The now ubiquitous idea that a company's culture is defined by a set of "core values" derives from the codification of McKinsey's internal notion of what constituted professionalism. Rather than expertise being a source of professional status, for consultants, performances of professionalism provides a resource for claiming expertise (Kipping 2011). Moreover, professionalism can be standardized and developed into a full-scale model of organization-McKinsey's famous"7s" model-which places "shared values" at the centre of organizational coordination. In short, corporate culture hi-jacked cultural analysis for a management product. ${ }^{7}$

It is of relevance to ask, why do consultants espouse this notion of culture? The idea that organizational culture is a totalizing force which can be engineered at will, whilst clearly rejected by anthropologists (Marcus 1998, Wright 1994), is also a very particular view in organization studies and the field of management. In a paper on risk culture in the finance industry since the 2007-8 financial crisis, Mike Power, Tomasso Palmermo and Simon Ashby make the observation that regulators, risk committees, and consultants have a tendency to selectively appropriate from the organizational culture literature in their problematization of risk culture (2014). In particular, literature from the 1980s, such as the work of organizational theorist Edward Schein, is favored. Schein, who espouses a deterministic notion of culture which can, vitally, be controlled, appeals to experts whose legitimacy rests on assertions of being able to change or at least strongly influence social reality. By contrast, more recent literature, that which emphasizes a more open, less deterministic conceptualization of culture (for example, Alvesson 2013), is sidelined. Schein's formulation of organizational culture closely resembles McKinsey's formulation of corporate culture; indeed Schein was a favorite intellectual source for Systeo consultants in their Powerpoint "deliverables." But it was always the specter of failure, that despite all the exhortations of management consultants such a notion of culture could not produce the desired subjectivities, which animated my investigation. Hence, the aim of this article is to draw attention to the various subjectivities inside the consultancy, rather than an analytical focus on subjectivation in the Foucauldian sense, which assumes the smooth production of subjectivities. Furthermore, I suggest that it is by comparing desired subjectivities, as delineated by management practices and discourses, with those that employees actually evidence that we can shed light on the character of knowledge that consultants sell.

According to Nigel Thrift, managerial knowledge, which is at its

\footnotetext{
${ }^{6}$ McKenna states that "the managing partners at McKinsey \& company created "corporate culture" as a strategic response to the declining demand for the firm's central "product" - the organizational study" (McKenna 2006: 193).

7 http://www.mckinsey.com/insights/strategy/enduring_ideas the 7s framework (accessed 16 April 2015).
} 
most basic concerned with the minutiae of interaction and human behavior, is performative in the sense that embodied performances of this knowledge are required for its authentication. (Thrift 2005: 96). In addition, he suggests that the prescriptive character of reflexive managerial knowledge is such that it "has the power to make its theories and descriptions of the world come alive in new built form, new machines and new bodies" (Thrift 2005: 11). This second notion of performativity bears close resemblance to Michel Callon's thesis of performation. Writing specifically about economic models, Callon (1982: 2) argues that economics "performs, shapes and formats the economy, rather than observing how it functions." This thesis has been taken up with gusto in the social studies of finance where scholars have demonstrated how financial equations and trading algorithms work not to represent but to intervene in the social reality of financial markets (Mackenzie 2006; Mackenzie et al. 2007). Management consultants also produce practical models-those that are actually used in business-which do not necessarily correspond to economic or management theory as taught in universities (Thrift 2005). In so doing, they play an important role in shaping every day business realities. However, it should be noted that the ways in which these models affect social forms is not necessarily isomorphic with the claims embedded in their theories. Hence, rather than focusing on whether or not models of corporate culture can be considered culture proper, I look at how practices and discourses of acculturation such as corporate citizenship, create the legitimacy for managerial interventions in the most basic forms of corporate life.

\section{Corporate citizenship and the performance of morality}

Writing about the "de-radicalization of CSR," sociologist Ronen Shamir observes that "the community" of CSR discourse can often refer not to local "stakeholders" but the employees of large corporations. He argues that: "by focusing on employee participation in CSR projects, by enlisting them to contribute time, money and knowledge, and by sharing with them the company's reputation as socially responsible, the normative control is deployed by transforming employees into a 'community' and by turning labour relations into a question of employees' satisfaction and loyalty" (Shamir 2004: 683). CSR initiatives provide myriad possibilities for employees to perform the company's core values. Inducting employees into being "good corporate citizens" constituted a pathway for them to become "Systeofied." As Peter Grantham, a consultant from the London office, put it: "CSR seeks to inspire our employees and reinforce cultural values about 'who we are' and 'how we operate."' In China, this injunction takes on a rather literal meaning. According to Stephanie Smith, Head of Global Giving, Systeo was only allowed to open offices in China on condition they provided educational and community investment. 
In autumn 2008 I participated in Systeo China's "flagship" corporate citizenship event-a charity bike ride across Sichuan province to raise money for victims of the devastating earthquake which had hit the region on May 12 of that year. To be considered for participation I had to donate at least one item to an online auction. Other employees would then bid for these gifts, the money going to the Sichuan relief effort. The fifteen employees with the highest bids, and thus who had raised the most money, would be selected automatically. The remaining twenty slots would be decided by putting all the other "sellers" into a lucky draw.

Just a couple of months after the auction I boarded a flight to Chengdu, the capital of Sichuan province, with all the other Beijing-based employees. Once there we boarded a coach which took us on a tour of the city before arriving at the hotel. Along with our flights and meals Systeo had paid for us to stay in a 4 star hotel in the downtown area. After 30 minutes to check-in and freshen up, we met outside the hotel for the bike fitting. Gleaming new mountain bikes were unloaded into the car park. British senior executive, Mark McDougall, had brought his own well-used racing bike. The bike mechanics enjoyed teasing him in broken English, saying that it was a great bike "maybe ten years ago." Conversations were stilted but jovial, as the participants-consultants drawn from the different China offices-started to get to know one another. We continued chatting over dinner. One consultant, Xing Feng, a native of Chengdu, was in hospital when the earthquake began. "I was lying in the hospital bed when the walls started to move; I had no idea what was happening," he recalled. The other participants listened with unwavering attention, some of them visibly moved. "This is my home and I know people who have lost their homes, friends or family members," he went on to say. His personal narrative contrasted with that of James Tsang, from Hong Kong but brought up in the US, who spoke in abstract terms about how "in these times, what with the financial crisis, it's good to give something back to society."

We cycled between fifty and seventy kilometres each day, covering one hundred and fifty kilometres altogether. Mark, the British senior executive, was my "chaperone." One of the best riders, he was usually at the front of the pack, but periodically he would hang back to check on those behind him. He would often cycle next to me, giving me advice on how to make better use of my gears and encouraging me with comments such as, "just imagine how amazing you're going to feel when you cross the finishing line-it's gonna be worth all the pain!” Saddle sores were the least of my worries. With a route that included motorways and dirt tracks through industrial processing zones, as well as the expected climbs up Emei Shan and Le Shan, the famous mountains of Sichuan, we found ourselves cycling in harsh conditions. Our clothes were splattered with mud and a thick layer of dirt covered our faces. The participants-middle-class, white-collar workers-could be forgiven for thinking they had signed up for a survival course, not a bike ride. The 
message that we needed to suffer to do good, that this was an exercise in being "outside your comfort zone," was deeply apparent.

Blocked roads, collapsed buildings, and piles of rubble became familiar sights on our journey. The "finishing line" was a construction site. A primary school that had been destroyed in the earthquake would be rebuilt, funded by Systeo. Led by the senior executives, we formed a procession of cyclists, greeted by cheers from local government officials, pupils and their parents. The pupils performed a song and dance routine. The consultants presented them with rucksacks stuffed with treats. Then the day's climax-a "ground-breaking" ceremony in which senior executives were photographed posing with shovels alongside government officials. The next day, we visited two more schools. Consultants dished out blankets and laptops. They asked the children if they had heard of Systeo and if they wanted to be management consultants when they grew up. Later we filed into the makeshift canteen and had lunch with the pupils, some of whom were dressed in the traditional costumes of the Yi minority. One little girl notable for her green eyes, so uncommon amongst Han Chinese, drew the most attention. Out came the digital cameras. Groups of consultants and children held their hands up, fingers adopting the "V" for victory symbol, and smiled to the beat of the flash.

By fetishizing the people they helped it would appear that Systeo employees considered them to be wholly different. The children were rural citizens, less sophisticated, and un-modern in comparison. Deciding who deserves help requires a process of differentiation. Workers considered the children to be of lower suzhi (quality)-a concept which has become central to processes of governance in post-Mao China, and is typically invoked as form of social classification which justifies inequalities of power, status and wealth between those with "high" suzhi and those "lacking quality" (Kipnis 2007). Yet, in some ways the children were not so different. Only the top fifty students (by test scores) were allowed to attend. Like the consultants, who were typically recruited from elite universities, they were high academic achievers-perhaps one day they would become consultants? The consultants were helping people they could both distance themselves from and identify with. Depicted as less fortunate versions of themselves, the precocious pupils of the destroyed Sichuan schools were the "safe" Other to which they could direct their good intentions.

Employees had signed up to a strange mix of endurance, selfdeprivation, and indulgence. Given that they spend at least five days a week inside an office, cycling one hundred and fifty kilometres across Sichuan was physically, as well as mentally, challenging. But these were isolated, contained challenges. Unlike the children they visited, the recipients did not stay in makeshift housing, but rather in a four star hotel. Similarly, eating simple dishes of plain vegetables and rice was a one-off experience of "the local," and not a mundane activity of everyday 
existence. These were also meticulously planned challenges; by contrast the children were faced with the ongoing instability, uncertainty and precarity of living in the aftermath of the earthquake. I point out these differences because it is precisely by drawing parallels with recipients-the creation of an "empathic zone"-that employees can be said to be experiencing "the Other" and thus testing themselves. It is this carefully calibrated testing of the self that is so covetable and definitive of the internal practice of CSR. The bike ride was designed to be experienced as a series of revelatory moments-about participants' own capabilities, their responses to adversity, their position in social hierarchies, and even the utility of their expertise. These revelatory moments were crucial to transforming the self: that is, to promoting the creation of new subjectivities. One might expect that employees returned to work with an improved ethic of graft. Perhaps, also they became more content in their everyday work, which might translate into a state of heightened passivity so making them easier to manage. Or most obvious, one might expect that they found meaning, a sense of purpose, in jobs which are defined by their inscrutability.

\section{Performing a"global" morality in post-Mao China}

Although long established in Systeo's older geographies (of North America and Western Europe), corporate citizenship was still in its infancy in China. "It's been hard to get traction-it's been difficult to build corporate citizenship in China," remarked Stephanie Smith, Head of Global Giving. Tentatively she suggested that that there was "not a strong heritage of charitable giving due to cultural norms." Stephanie implied that Chinese employees constrained by "their culture" did not grasp the idea of charity-giving without the expectation of return-a problem that suggested, in her words, "a need to increase employee awareness." This was especially important because "corporate citizenship is something that develops organically in each region," being comprised of "employee driven initiatives [and hence] often takes on a 'local flavor."'

As Carolyn Hsu has pointed out, voluntary giving is not a foreign concept to Chinese who have long seen it a moral obligation to provide for kin in need (2008: 84). However, giving to strangers-a central principle in Western charitable giving-is not valorized and has only been recently introduced (ibid.; also see Rolandsen 2008). Hsu examines the historical development of Project Hope-one of the first, and most successful, charities in the post-Mao era-which was set up to raise funds for rural schools. It elicits donations from individual and corporate donors; the latter includes, notably, Systeo. According to Hsu, the main problem facing charitable organizations in China is that Chinese people find it difficult to trust strangers unless they are engaged in reciprocal relations built up through gift exchanges. As well as noting that charity is a culturally conditioned perception based on a Western conception of universal love, 
which can thus be applied to those near and distant to us, Hsu observes that such cultural hurdles can be overcome by drawing on existing schemas of moral legitimacy. For example, by recasting hitherto anonymous donations as personalized, and hence trust generative, relations between donor and recipient. Stephanie's assertion, shared by many expatriates, that Chinese employees are held back by a set of norms or cultural values, fails to grasp how notions of charity are predicated on configurations of social relations which are not necessarily shared across contexts. As we will see, this failure to consider social relations would not be the only threat to the realization of the desired corporate subjectivity.

During the bike ride there were nightly team briefings, in which consultants were invited to give their thoughts on the day. One consultant commented that one of the children, of the schools we had visited, had the same mobile phone as him. "Do they really need our help?" he intoned. A few of us went to a bar afterwards where the discussion continued. "It's different for us," said Chen Jin, a consultant from Beijing, referring to mainland Chinese employees as opposed to expatriates. "Obviously we have very different lives from these children, but you know thirty, forty years ago...we weren't so different." Since market reforms were introduced income inequality has skyrocketed and Chinese society has become increasingly stratified. That said, the suggestion that urbanites and rural citizens were equal under Mao is at best nostalgic. Various scholars have pointed out that rural China, although privileged in (Chinese communist) party discourse (Bach 2010), was continuously decimated and devalued for the sake of creating urban China as the vision of socialist modernity (Siu 2007). Nevertheless, Chen Jin's comments do show how memories of China's socialist past continue to inform how people experience and make sense of present-day social differentiation.

Chen Jin had questioned whether these communities were truly deserving of corporate aid on the basis that the recipients appeared to be too similar to them. I should stress that Chen Jin and other Chinese employees were not disengaged from the plight of China's rural poor. They would often forward emails to each other asking for donations to charities dedicated to improving the living standards for rural children. Containing harrowing images of teary-eyed children eating scraps of food, carrying sacks of sticks on their back, hands and faces raw from the cold, these emails stated emphatically who was the deserving subject of charity. Systeo's CSR initiatives had disrupted the overdrawn, if not patronizing, image of the rural child as the uncivilized, inferior Other to the modern, middle-class urbanite that employees propagated.

Yet, this was precisely the opposite of what was intended. CSR initiatives are predicated on, and serve to magnify, the inequality between recipients and donors. Whether represented as integral to their business model, or simply old-fashioned corporate giving, CSR has innovated little on the imperialistic trope of Western folk helping to civilize the 
developing world. It is by highlighting inequalities that CSR initiatives gain their moral legitimacy: who can truck with measures to help those who are worse-off? It is apparent that certain representations of communities are necessary to legitimate CSR as a way of "giving back" to society. If Chinese employees do not see themselves as superior to the recipients of their goodwill, then the moral imperative that drives the initiative is lost. They might begin to wonder why they have made personal sacrifices-not just with the objects they put up for bidding, but also four days of annual leave, four days that could have been spent with their families-to cycle across Western China. They have suffered, but for what and for whom?

At the end of the event, we were put into groups of three and asked to write an article together based on our experience. The best articles would be published in the company CSR magazine. I was put with $\mathrm{Chen}$ Jin and $\mathrm{Yu} \mathrm{Na}$, two consultants from Beijing. We sat together on the bus back to Chengdu to discuss what we might write. Yu Na asked a rhetorical question: “the government would provide help if Systeo didn't, right?" to which Chen Jin agreed. From conversations on the road I sensed that many employees had chosen to participate in the bike ride in order to see with their own eyes the destruction wrought by the earthquake. A distrust of Chinese media representations which had saturated primetime TV, night after night, served as one motivation. Buying into the wave of Chinese nationalism that was fuelled by this media explosion was another. As we passed a refuge of temporary shelters, metal cabins with uniform blue roofs, Lisa Teng, a consultant based in Shanghai, pointed out the grand, grey brick government offices in close proximity. "Buildings for officials get rebuilt before homes for ordinary people-that's China for you," she lamented. Even though employees thought that the relief effort would be marred by corruption, they took it for granted that the state would be leading the operations.

As Catherine Dolan has argued, the practice of CSR typically claims its legitimacy, or at least rhetorical traction, by claiming to plug gaps in development produced by the absence of the state (Dolan 2010). The lack of formal standards or regulation-whether concerning labor practices or factory emissions, for example-is used to justify the growth of CSR practice in these areas. In the United States, where state intervention is often treated with suspicion, the idea that corporations will intervene in everyday life-indeed that they should because they provide better, more efficient solutions-is widely accepted. In China, however, the state is seemingly omnipresent. Basic choices concerning human reproduction, media consumption, one's place of residency, are all subject to state intervention. This control is enacted through paternalistic ties, not dissimilar to the kind invoked by the practice of CSR. This point is exemplified by the media construction of "Grandpa Wen," Wen Jia Bao, then Premier of the PRC, the 66 year-old poster "boy" of the relief effort. TV crews and journalists document him in the trenches, consoling 
homeless, maybe even orphaned, children-the victims of the earthquake. Such media narratives drive home the message that the patron of the relief effort was the Chinese Communist Party, not Systeo or any other Western donor. Stephanie Smith and other employees, expatriate and Chinese, involved in building Systeo China's CSR programme, had not thought through how a strong, paternalistic, state would impact the effectiveness of CSR to engage employees. In this context, the value that Systeo brought to the relief effort was not apparent. And thus the key CSR message, to both external stakeholders and Systeo employees, that Systeo is there to "make a difference," failed to materialize.

Months after the bike ride I had lunch with a few consultants. The conversation turned to the topic of corporate citizenship. One consultant, Joanna Li, told me that they do not yet have the culture (wenhua) for such initiatives. She said that "not long ago the government took care of everything-your work, where you lived, people in need." She was referring to Mao's "iron bowl"- the set of cradle to grave benefits, including life-long employment, which prevailed under socialism. "People don't really consider giving to others; it's just not in the culture right now," she explained. Joanna's comments seemed to imply that culture, a bit like older ideas of development, was based on a linear teleology. One day Chinese culture would "catch-up" with the West, and then giving to charity would be normalized. Expected even. Until then Chinese "culture" would hold back the implementation of CSR. Joanna's thinking seems remarkably close to that of Stephanie Smith, the Head of Global Giving-recall her remark that "the norms" of giving were not yet established in China.

The idea that there exists a teleology of development which is matched, or evidenced, by a teleology of mentalities may not be anything new. What is interesting is how, in this context, culture is seen as the driver of these teleologies, in contrast to standard modernist notions of development in which culture is posed as a hindrance to producing rational, liberal citizens. It may be the case that this reversal simply reflects the fact that culture is a dominant discourse of management consultancy and is seen as a model for controlling social reality. As I have already pointed out, consultants, despite being hired to create efficiency through the implementation of standardized, rational and technocratic forms of management, in fact base much of their expertise on culture. But the recourse to culture, and in particular the invocation of cultural difference for explaining the failure to conform could also be read as an unprovocative way of side-stepping managerial control. That is to say, Chinese employees are also adept at apprehending culture for their own self-interest. 


\section{Providing a "high level experience"}

The money raised from the bike ride bolstered the already considerable amount raised through a donation drive launched in the immediate aftermath of the earthquake, in which the company matched every renminbi donated by an employee. In just one week Systeo China and its employees had donated over 2 million renminbi (U\$S180,000) to the relief effort. Employees' generosity called into question Stephanie's assertion that "the norms" of giving were not yet established in China. Given that a sizeable donation had been made, and with ease, why was it necessary to organize a fund-raising bike ride? Some insight can be found by looking at who was eligible to participate. Any employee could donate money, but only permanent employees received the email explaining how they could join in. ${ }^{8}$ As we will see, corporate citizenship is seen as a form of human investment, which is reserved only for those the company seek to retain.

Just six months after the bike ride I was hired as Systeo China's very first "Corporate Citizenship Coordinator." In fact the job was created with me in mind. The experience I gained working in the Human Capital Strategy Programme was seen as especially relevant, a point I will return to later. Also, having participated in the bike ride, I was well informed to help organize the following year's bike ride, the main task of this position. So I joined a bike ride committee comprised of consultants who had volunteered their project management and logistics skills, as well as time, to the CSR Programme. Over a series of conference calls we hammered out a rough sketch of the event; it was my job to translate these ideas into fluent, exciting communications which would be sent directly to employees and uploaded onto the company intranet.

Very quickly I realized that we were planning a much more ambitious event than in previous years. There would be more participants-up to sixty employees and, for the first time, the bike ride would be open to employees outside of China, as well as those based in the China offices. This was the idea of Emma Jiang, senior executive and bike ride lead. The participation of employees from North America and Europe would, according to her, show that Systeo China was a truly global entity. Another reason for pursuing this arrangement was that it might encourage Chinese employees to take part. Most were between their mid20 s and 30s and, unlike their parents, had only ever been employed by foreign companies. They saw themselves as part of a generation of Asian cosmopolitans who wanted to work in "global" environments (Hoffman 2010, Hsu 2005). CSR initiatives such as the bike ride were almost unheard of in Chinese enterprises. Their existence signalled immediately

\footnotetext{
8 Because I was not a permanent employee I should have been disqualified. However, other colleagues lobbied the senior executive who was overseeing the event, telling her about the unpaid work I had done for Systeo's corporate citizenship initiatives. Thus, she decided to make an exception.
} 
that these were not "local" entities. Moreover, such events allowed employees to actually meet and interact with Europeans, Americans, and Australians.

Emma also expected "foreign" employees to jump at the chance of cycling in China. But getting access to them would not be a straightforward matter. We needed to "reach out" to the CSR leads of the different Systeo geographies. Their Western names indicated what the employee directory confirmed-only Systeo offices in the global North employed specialist CSR professionals. China did not have a CSR lead. As contracted CSR coordinator, I was the next best alternative. Hence, I was asked to present Powerpoint detailing our plans for the coming bike ride and background information on the previous year's event. David Kraus, the German lead, was to first to comment: "I know what the [German] senior executives will say: 'that's nice but what does a bike ride have to do with Systeo?'” The connection between corporate citizenship activities and Systeo's core business was not apparent. Amelia, the US lead, had different objections. She said she would only want the US geography to be involved if we could "deliver a high level experience that rivals the Everest event." The year before employees, notably only those from the global North, had been invited to "challenge themselves" by trekking to the Mount Everest base camp, an event of great complexity to organize, which was collectively judged a "resounding success." I was struck immediately by Amelia's emphasis on the individual employee's experience, rather than on the charities for which the employees would be raising money. Cathleen Doyle, the Ireland CSR lead, seemed to share her concern interjecting with, "does anyone on the global corporate citizenship team know you're organizing this?" The tone in which Cathleen asked her question seemed to suggest that we, the Chinese corporate citizenship team, were errant children going behind the backs of our "Global" parents. The implication was that if Global was not involved then they-the Western CSR leads-could not ascertain the quality of the event, the experience we would deliver, which made them wary of letting "their" employees participate.

In fact Global were the ones who suggested we contact the CSR leads. Sitting at my desk, staring at my phone as if it could talk back to me, I felt extremely uneasy. There was something untoward in their questioning, something that suggested we were not just talking about logistics or CSR. Our competency, our skill at performing corporate ethics, was under attack. Amelia stated in no uncertain terms that she would not be sending out our communications to all US employees. In effect she was refusing access. Only those who had signed up to corporate citizenship interest lists, and Asian American employees, would be made available to us. I was floored. There was a mailing list comprising only Asian American employees? In a "global" company? And why would only Americans of Asian ethnicity be interested in participating? Amelia's comments seemed to rehearse my own observation that CSR "works" when employees can 
identify with the recipients of their goodwill. Except she seemed to suggest that a common ground could only be found on the basis of ethnicity.

There were also controversies over who would be a deserving recipient: "Where do you draw the line? There are lots of charities which need our support in Ireland so why should we help raise funds in China?" remarked Cathleen. Emma trotted out the global narrative, that as a global company Systeo should encourage its employees to participate in charity events in different geographies. Met with awkward silence, Emma added: "the foreigners, I mean the expatriates who participate in the bike rides...you should see the children's faces-they have never seen a foreigner before." I got her point that having expatriates involved gives Chinese recipients a much greater sense of Systeo, that it is a global entity with employees drawn from around the world. At the same time I could not shake the feeling that we-the China corporate citizenship team-were selling ethnic voyeurism to white employees. The gap between recipient and donor had suddenly been amplified. Such comments did not necessarily suggest a paucity of professionalism or inaccuracy of observation-I had seen for myself the enchanted faces that she spoke of. Rather it appeared that Emma was unprepared for the CSR leads' spiky questions and negative feedback.

We had not anticipated the CSR leads would act as gatekeepers to employees. If doing good was integral to corporate citizenship activities in all geographies, as is suggested by Stephanie Smith, the Head of Global Giving, in Systeo's leadership videos and the company magazine, then why was employee participation so tightly policed? The finances of corporate citizenship were instructive here. Overall, the bike ride committee hoped to raise at least two hundred and fifty thousand renminbi (US\$38,000) through the event. However when going through the project budget I found out that less than ten per cent of this money would go to charity. Most of it would go into covering the event's costs: the hotels, the flights, the meals, the bike rental, bike mechanics and third parties (for instance, agencies specializing in local logistics). The injunction from Amelia, the US lead, to "deliver a high-level experience" belied an overarching objective, not to raise money for charity, but to create what were termed "engaged employees."

As I would later find out by reading the business case for my role of China corporate citizenship coordinator, corporate citizenship activities are seen as an input to human capital. Systeo sell and practice internally the idea that CSR is a way of making "engaged employees," those who actively contribute to the creation of shareholder value. Every CSR lead is under pressure to demonstrate how they have improved employee engagement-this is how their performance is evaluated-which explains why they are wary of letting "their" employees participate in initiatives organized by other geographies. 
As an internal consultant to the "Human Capital Strategy Programme" I was privy to the range of activities-intra firm dating events, sports clubs, flexible work arrangements-which were considered deserving of company investment. CSR was yet another example. The naïve theory is that by participating in such activities employees develop a more positive relationship with the company so enhancing productivity, and, in turn, shareholder value. Although I found that the connection with shareholder value was rarely mentioned (it was only made apparent in diagrams which measured the improvement in "employee engagement" in terms of total shareholder return), on occasion it was explicitly referred to. For example, in an interview with Systeo's Head of Global Giving, Stephanie Smith stated baldly that corporate citizenship initiatives "need to prove return of investment will come" in order to be implemented.

Writing about the partnerships between big business and NGOs Robert Foster (2014) argues that contemporary global capitalism uses consensus as a way of diffusing potentially conflictual relationships and agendas, and in doing so weds ethical praxis with the creation of shareholder value. This kind of bridging between ethics and profit through strategic collaborations is termed "connected capitalism." The use of CSR as a tool of acculturation is but another example of how external associations or partnerships, such as investing in local schools destroyed by natural disasters, can be apprehended for the moral aestheticizing of business as usual.

\section{Conclusion}

In this article I have examined the work of "re-engineering" Chinese employees in a global ethics through the internal practice of CSR. I have shown how activities of "doing good," by inducing employees to perform a decontextualized form of morality, aim to create a discursive moral self. The content of this morality, however, lacks a subterranean ethics. Instead, employees are invited to perform the company's "core values," which are more codifications and commodifications of professionalism (McKenna 2006: 193) than ethical coordinates for social action. Hence morality is defined in negative terms-as what it is not. Through revelation corporate citizenship activities are designed to create affective ties which would appear to be defined by the absence of financial concerns. The actual amount raised by the bike ride for the charity is never disclosed, somewhat strange given that this is the explicitly narrated objective of the event. Hence employees, apart from the bike ride committee, are not aware of the slim margins of charitable giving. At the same time, employees do not question the comparative luxury in which they are "challenged." It would seem that employees are encouraged to see such changes to the self as not driven by profit. In this way they can be said to have been "engaged." 
Yet sentiments which derive their meaning from the elision of finance are generated with the view to making subjects who maximize the creation of financial value. One of the central contradictions of CSR is that moral legitimacy is drawn through the performance of extra-financial concerns, yet moral authority is generated for the purposes of finance. How this contradiction is effaced is of particular interest. We find that the failure to display the correct ethical dispositions is, in the first place, denigrated as a problem of culture. Chinese employees are seen as somehow less developed, culturally speaking, than their Western colleagues. Their "failure" is that they do not display the right norms of giving and benevolence befitting global professionals-they are exoticized to explain their lack of "professionalism." We find that, to be deemed worthy, recipients of corporate aid are also exoticized. There is a common theme of ethical action being legitimated through processes of making strange what might otherwise be familiar.

However, in the analysis presented above, we see that such attempts at othering are not always successful in the post-Mao context. The problem is not only that Chinese employees see the targets of their goodwill as too similar to themselves. They also question the legitimacy of corporate intervention. In post-Mao China, where state power is still hegemonic, the rhetorical traction of CSR is somewhat decimated. This would suggest that the efficacy of CSR to produce the "right" performances of morality is not, as the discourse suggests, universal. Rather the desired moral self is imagined in continuation with older structures of paternalism and corporate philanthropy. Although there is nothing intrinsically "Western" about the marriage of ethics to capitalism, the discursive effects of CSR rest upon certain assumptions of how capitalist practices relate to local development, which derives from a long history of Western capitalism. Far from producing "global" subjects, practices of corporate responsibility aim to bolster and re-assert corporate power in the minds of employees, as well as in public perception.

\section{References}

Alvesson, M. (2013). Understanding organizational culture. Sage Publications.

Bach, J. (2010). "They come in peasants and leave citizens:" Urban villages and the making of Shenzhen, China. Cultural Anthropology, 25 (3), 421458.

Benson, P. (2014). Corporate Paternalism and the Problem of Harmful Products. PoLAR: Political and Legal Anthropology Review, 37 (2), 218230. 
Callon, M. (1998). Introduction. In M. Callon (Ed.), The laws of the markets. Oxford: Blackwell.

Cefkin, M. (2010). (Ed.) Ethnography and the corporate encounter: Reflections on research in and of corporations. New York \& Oxford: Berghahn Books.

Dolan, C., \& Johnstone-Louis, M. (2011). Re-siting corporate responsibility: The making of South Africa's Avon entrepreneurs. Focaal, 60, 21-33.

Dolan, C. S. (2010). Virtual moralities: The mainstreaming of Fairtrade in Kenyan tea fields. Geoforum, 41 (1), 33-43.

Downey, G., \& Fischer, M. (2006). Introduction. In G. Downey \& M. Fischer (Eds.), Frontiers of capital: Ethnographic reflections on the new economy. Durham N.C. \& London: Duke University Press.

Hoffman, L. M. (2010). Patriotic professionalism in urban China: Fostering talent. Philadelphia, PA: Temple University Press.

Holmes, D. R., \& Marcus, G. E. (2006). Fast capitalism: Para-ethnography and the rise of the symbolic analyst. In G. Downey \& M. Fischer (Eds.), Frontiers of capital: Ethnographic reflections on the new economy. Durham, N.C. \& London: Duke University Press.

Hsu, C. (2005). A taste of "modernity:" Working in a western restaurant in market socialist China. Ethnography, 6 (4), 543-565.

Hsu, C. (2008). "Rehabilitating charity" in China: The case of Project Hope and the rise of non-profit organizations. Journal of Civil Society, 4 (2), 8196.

Kessler, D. (2006). Nationalism, theft and management strategies in the information industry of Mainland China. In C. K. Lee (Ed.), Working in China: Ethnographies of labor and workplace transformation. London: Routledge.

Kipnis, A. (2007). Neoliberalism reified: suzhi discourse and tropes of neoliberalism in the People's Republic of China. Journal of the Royal Anthropological Institute, 13 (2), 383-400.

Kipping, M. (2011). Hollow from the start? Image professionalism in management consulting. Current Sociology, 59 (4), 530-550.

Kirsch, S. (2014). Imagining Corporate Personhood. PoLAR: Political and Legal Anthropology Review, 37 (2), 207-217.

Lynch, D. C. (1999). After the propaganda state: Media, politics, and "thought work" in reformed China. Stanford, CA: Stanford University Press.

MacKenzie, D. A., Muniesa, F., \& Siu, L. (2007). Do economists make markets? On the performativity of economics. Princeton, NJ: Princeton University Press. 
MacKenzie, D. A. (2006). An engine, not a camera: How financial models shape markets. Cambridge, MA \& London : MIT Press.

Marcus, G. (Ed.). (1998). Corporate futures: The diffusion of the culturally sensitive corporate form. Chicago \& London: University of Chicago Press.

Mazzarella, W. (2003). Shoveling smoke: Advertising and globalization in contemporary India. Durham, N.C. \& London: Duke University Press.

McKenna, C. D. (2006). The world's newest profession: Management consulting in the twentieth century. Cambridge \& New York: Cambridge University Press.

Moeran, Brian. (2006). Ethnography at work. Oxford: Berg.

Nafus, D. \& Anderson, K. (2006). The real problem: Rhetorics of knowing in corporate ethnographic research. Proceedings from Ethnographic Praxis in Industry Conference.

Ong, A. (2006). Corporate players, new cosmopolitans, and guanxi in Shanghai. In M. Fischer \& G. Downey (Eds.), Frontiers of capital:

Ethnographic reflections on the new economy. Durham and London: Duke University Press.

Power, M., Palermo, T., \& Ashby, S. (2014). Searching for risk culture in financial organizations. Paper presented at the Social Anthropology seminar series, Dept. of Anthropology, University College London.

Rajak, D. (2014). Corporate memory: Historical revisionism, legitimation and the invention of tradition in a multinational mining company. PoLAR: Political and Legal Anthropology Review, 37 (2), 259-280.

Rajak, D. (2008). “Uplift and empower:” The market, morality and corporate responsibility on South Africa's platinum belt. Research in Economic Anthropology, 28, 297-324.

Rajak, D. (2011). In good company: An anatomy of corporate social responsibility. Stanford, CA: Stanford University Press.

Rolandsen, U. (2008). A collective of their own: Young volunteers at the fringes of the Party realm. European Journal of East Asian Studies, 7 (1), 101-129.

Ross, Andrew. (2006). Fast boat to China: Corporate flight and the consequences of free trade-lessons from Shanghai. New York: Pantheon Books.

Shamir, R. (2004). The de-radicalization of corporate social responsibility. Critical Sociology, 30 (3), 669-689.

Shever, E. (2010). Engendering the company: Corporate personhood and the "face" of an oil company in metropolitan Buenos Aires. PoLAR: Political and Legal Anthropology Review, 33 (1), 26-46.

Siu, H. (2007). Grounding displacement: Uncivil urban spaces in postreform South China. American Ethnologist, 34 (2), 329-350. 
Thrift, N. J. (2005) Knowing capitalism. London: SAGE Publications.

Welker, M. A. (2009). "Corporate security begins in the community:"

Mining, the corporate social responsibility industry, and environmental advocacy in Indonesia. Cultural Anthropology, 24 (1), 142-179.

Wright, S. (Ed.). (1994). Anthropology of organizations. London:

Routledge.

Kimberly Chong is a teaching fellow in social anthropology at University College London. Trained in economics, sociology and anthropology, Kimberly has carried out research which examines forms of expertise in connection with China's economic development. Recent publications include an article on how fund managers utilize conviction narratives to make decisions under conditions of radical uncertainty, published in Socio-Economic Review. She is currently working on a book manuscript about management consulting in China and the practices of financialization, provisionally titled The Work of Financialization, which will be published by Duke University Press. She may be reached at kimberly.chong@ucl.ac.uk 